\title{
Small mammal remains from the Temple of Neptune, a window on the ancient landscape of the Sele Plain (Southern Italy)
}

\author{
Armando Nappi
}

\begin{abstract}
The Sele Plain was once a marshy area that has recently been reclaimed. The analysis of skull and dental remains of small mammals, collected during the restoration of the Temple of Neptune, testifies the ancient existence of ecosystems that have now been greatly reduced in this area. In particular, the high percentage of remains of Arvicola italicus, a rodent that is now very rare throughout Italy, confirms the presence of aquatic environments.
\end{abstract}

Key words: archaeology, Campania, ecology, Rodentia, Soricomorpha.

Riassunto - Resti di piccoli mammiferi dal Tempio di Nettuno, una finestra sull'antico paesaggio della Piana del Sele (Sud Italia).

La piana del Sele, era un tempo un'area paludosa che in tempi recenti è stata sottoposta a bonifiche. L'analisi di resti cranici e dentari di piccoli mammiferi, raccolti durante le operazioni di restauro del Tempio di Nettuno, testimonia l'antica esistenza di ecosistemi oggi fortemente ridotti in quest'area. In particolare, l'alta percentuale di resti di Arvicola italicus, roditore oggi in forte rarefazione sull'intero territorio nazionale, conferma la presenza di ambienti acquatici.

Parole chiave: archeologia, Campania, ecologia, Rodentia, Soricomorpha.

\section{INTRODUCTION}

The study of qualitative-quantitative faunal compositions of small mammals in a certain territory provides useful information on the environmental characteristics of the territory itself, as this kind of associations are the product of different parameters such as temperature, moisture, vegetation and anthropic impact (Contoli, 1976, 1980, 1981; Aloise \& Contoli, 1984; Castelli \& Contoli, 1985; Contoli, 1985, 1988; Marzilli \& Contoli, 1991; Nappi, 2004b). For the very same reason, these remains are widely studied in palaeontology (Kowal-

Museo civico di Storia Naturale, Via Cortivacci 2, 23017

Morbegno (SO), Italia.

E-mail: armando.nappi@alice.it

(C) 2021 Armando Nappi

Received: 23 March 2021

Accepted for publication: 22 July 2021

Online publication: 29 October 2021 ski, 1966; Chaline, 1970, 1973, 1977, 1981; Kowalski, 1992), providing, for instance, good indications of the climate changes occurred during the glacial and interglacial periods of Pleistocene. Also in relation to historical periods, the analysis of bone and dental remains of small mammals can be useful in reconstructing any possible environmental changes that occurred due to both natural and anthropogenic causes (Kotsakis \& Ruschioni, 1984; Vigne, 1996; Pardiñas et al., 2000; Bon et al., 2001; Cuenca-Bescós et al., 2009; Lopéz-García et al., 2013a, 2013b).

Based on these considerations, I found it interesting to study the mammal remains from the deposits of soil and debris accumulated over time in parts of the Temple of Neptune in southern Italy and recovered during restoration work (De Palma, 2019). The present work is a follow up of an earlier note derived from a partial analysis of the material (Nappi, 2010).

\section{MATERIALS AND METHODS}

The Temple of Neptune $\left(40^{\circ} 25^{\prime} 11,70^{\prime \prime} \mathrm{N}\right.$, $\left.15^{\circ} 00^{\prime} 19,24^{\prime \prime} \mathrm{E}\right)$, dated around the middle of the $5^{\text {th }}$ century B.C., is located in the municipality of Capaccio, province of Salerno (Campania, southern Italy) (Fig. 1).

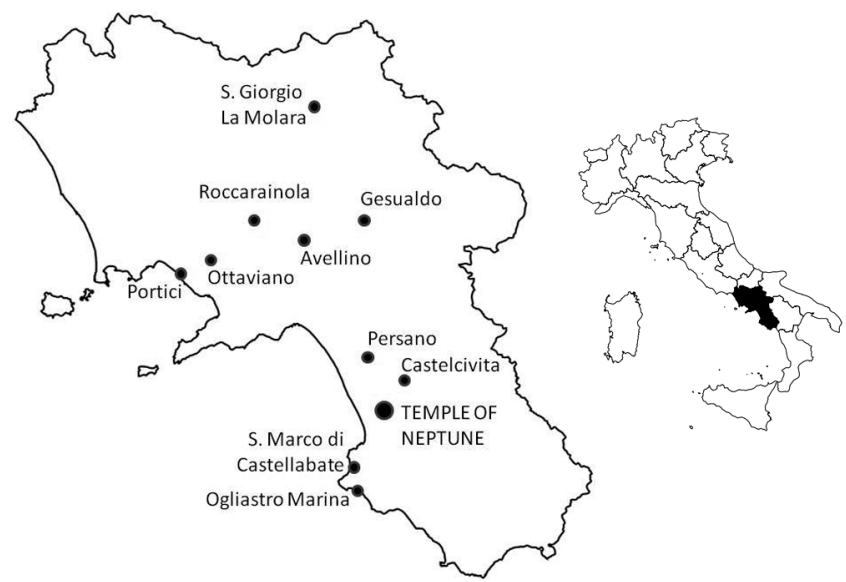

Fig. 1 - The location of the Temple of Neptune and other localities considered in the text. / La posizione del Tempio di Nettuno e di altre località menzionate nel testo. 
From a geographical point of view, the area is included in the Sele Plain, a region that was deeply altered by man in the last centuries. In particular, this area was characterized in the past by extensive marshes, which then underwent intense reclamation.

Cranial and dental remains of small mammals recovered during the restoration works of the Temple of Neptune were collected and used for the analysis. The identification was performed with binocular stereoscopic microscope according to the criteria proposed by Nappi (2001) and by Amori et al. (2008). Problems that arose during identification are discussed in the "Results and discussion" section of this paper. The count of individuals was based on the criterion of the minimum number of individuals, usually calculated considering the more representative hemimandible (right one or left one) for each taxon (Nappi, 2011).

Chiroptera and Talpidae were excluded from the calculation of the indices, while the wood mice (Apodemus sp.) were overall included as a genus.

The Margalef index was calculated in the form $\mathrm{D}=(\mathrm{S}$ - 1)/ $\log N$, where $S$ indicates the total number of taxa (the species in most cases, or the genus in the case of Apode$m u s$ ) and $\mathrm{N}$ indicates the total number of individuals.

The Trophic Level Index (TLI) was calculated as Soricidae/total mammals (Contoli, 1980).

The calculation of agronomic-environmental index (A) is expressed in its original formula as a ratio Cricetidae/ Muridae (Contoli, 1980) that is to say taxa mostly linked to open areas/taxa mostly linked to wood or bushy areas; in this case I decided to follow Zangirolami (1988/89) to exclude Myodes glareolus (a species associated with woods) for the Cricetidae. For similar reasons, I decided to exclude Arvicola italicus, a species linked to water environments, and I chose instead to add $M$. glareolus to denominator, whose agronomic-environmental index was calculated with the following formula: Cricetidae - $(M$. glareolus + A. italicus)/Muridae + M. glareolus .

The thermoxerophilia index was calculated as TX $=$ Crocidurinae/Soricidae (Contoli, 1980).

The values of the indices listed above were compared with those calculated for 10 sites in Campania (Fig. 1) whose qualitative and quantitative data on small mammal populations were obtained through the study of barn owl Tyto alba pellets.

Taxonomic arrangement and nomenclature follow Loy et al. (2019).

The studied mammal remains are kept at the Istituto Centrale per il Restauro, Rome.

\section{RESULTS AND DISCUSSION}

Considering their location within the temple, the remains examined were most likely the result of piles of pellets produced by nocturnal birds of prey, known to habitually roost in buildings.

The sampled remains were in quite good conditions of preservation so that species identification was possible for most of them. Only for most remains of the genera Talpa and Microtus and for all those of the genus Apodemus, identification problems have been encountered at species level.
As regards to the genus Talpa, the characters useful to distinguish $T$. caeca from $T$. romana (the two species present in Campania) were not always evident in the remains. In the genus Microtus, the teeth were almost completely missing, while for Apodemus, this problem is to be added to a generalized fragmentation of the skulls. Only for very few remains, it was possible to detect the finest characters, such as the rear edge of foramina incisiva surpassing the level of front edge's roots in the first upper molars and in the fourth and seventh tubercles of the same molars united.

These morphologies are typical but not exclusive of A. sylvaticus. On very few partially complete skulls, it was possible to calculate a morphometric index (Amori et al., 1986) used to separate A. flavicollis and A. sylvaticus, and its value was in the overlap range. The difficult discrimination between A. flavicollis and A. sylvaticus due to North-South morphological variations is well known, leading the former species in particular to be frequently mistaken for the latter (Niethammer, 1969). A synthesis of the identification problems of the two species Apodemus in Italy is offered by Amori et al. (2008). Also for water shrews belonging to the genus Neomys, knowing the difficulties of determination at specie level, it was preferred to leave a margin of uncertainty about the proposed identification. For this reason, it was chosen to refer to $N$. cfr. milleri, being not possible to easily detect all useful diagnostic characters on the skull and on the mandibles to give a sounder identification.

The complete list of identified mammalian taxa is reported in Table 1. Even though it was not possible to date the remains with an absolute method, anyway one could make some historical-faunistic considerations. The most interesting aspect of this first analysis is the abundance of Italian water vole Arvicola italicus, a rodent whose presence testifies of humid environments now rarefied. In addition, the ancient presence of this vole now in strong recession in Italy due to loss and degradation of its wet habitat (Nappi, 2004a; Cagnin, 2008) represents an interesting faunal record at national scale.

In Campania, the species is included in the "Vulnerable" IUCN category (Carpino \& Capasso, 2012) and in recent times it was certainly present in the territories of Partenio, between Naples and Avellino (Caputo, 1989; Capolongo \& Caputo, 1990; Capasso \& Carpino, 2008) and of Garigliano, province of Caserta (Scaravelli \& Priori, 2009). In the Vesuvius area (province of Naples), in particular, it has no longer been reported (Maio et al., 2000; Capasso et al., 2009) after the end of the 1970s (Dinardo, 1991b). An old record for the Picentini Mountains, province of Avellino (Pasa, 1959) was followed by a recent one in 2013 (Raicaldo, 2020).

In the province of Salerno, not counting the case reported here, remains of $A$. italicus were found in the Ausino Cave (Barbera et. al., 1987; Jancarik \& Horacek, 1988), which probably date from the Copper Age (Jancarik \& Horaceck, 1988). At present, the fact that this rodent has not been found around Paestum (Russo, 1997), Ausino Cave (Russo \& Maglio, 1996) and other sites in the province of Salerno (Nappi, 1998/99, 2000) is not conclusive evidence of its disappearance in situ, but it can certainly testify to a rarefaction of this species. Another report to 
Tab. 1 - Qualitative-quantitative composition of the small mammals' population of the Temple of Neptune, campinferred from the analysis of bone and dental remains. $\mathrm{N}$ : minimum number of individuals. / Composizione quali-quantitativa della popolazione di piccoli mammiferi del Tempio di Nettuno, dedotta dall'analisi dei resti ossei e dentari. N: numero minimo di individui.

\begin{tabular}{|c|c|c|}
\hline Taxa & $\mathbf{N}$ & $\%$ \\
\hline Myotis myotis & 2 & 0.26 \\
\hline Vespertilionidae sp. & 4 & 0.45 \\
\hline Tot. CHIROPTERA & 6 & 0.68 \\
\hline Sorex samniticus & 2 & 0.26 \\
\hline Neomys cfr. milleri & 3 & 0.34 \\
\hline Tot. Soricinae & 5 & 0.56 \\
\hline Suncus etruscus & 2 & 0.26 \\
\hline Crocidura leucodon & 50 & 5.64 \\
\hline Crocidura suaveolens & 122 & 13.75 \\
\hline Crocidura cfr. suaveolens & 1 & 0.11 \\
\hline Crocidura sp. & 3 & 0.34 \\
\hline Tot. Crocidurinae & 178 & 20.07 \\
\hline Tot. Soricidae & 183 & 20.63 \\
\hline Talpa romana & 4 & 0.45 \\
\hline Talpa sp. & 13 & 1.47 \\
\hline Tot. Talpidae & 17 & 1.92 \\
\hline Tot. SORICOMORPHA & 200 & 22.55 \\
\hline Eliomys quercinus & 2 & 0.26 \\
\hline Muscardinus avellanarius & 8 & 0.90 \\
\hline Glis glis & 4 & 0.45 \\
\hline Tot. Gliridae & 14 & 1.58 \\
\hline Arvicola italicus & 238 & 26.83 \\
\hline Microtus savii group & 30 & 3.38 \\
\hline Microtus sp. & 172 & 19.39 \\
\hline Tot. Cricetidae & 440 & 49.61 \\
\hline Apodemus sp. & 193 & 21.76 \\
\hline Rattus rattus & 19 & 2.14 \\
\hline Rattus sp. & 6 & 0.68 \\
\hline Mus musculus & 3 & 0.34 \\
\hline Muridae sp. & 6 & 0.68 \\
\hline Tot. Muridae & 227 & 25.59 \\
\hline Tot. RODENTIA & 681 & 76.78 \\
\hline TOTAL & 887 & - \\
\hline
\end{tabular}

be verified for the Salerno province, dated 1994, comes from the Tanagro River basin (Carpino \& Capasso, 2012). More recently, the Italian water vole has been found along the Sarno River (Raicaldo, 2020). The query for museum records returned a single specimen collected in Salerno on 15 March 1903 and kept at the Zoological Museum 'La Specola' in Florence with catalogue number 6057 (P. Agnelli, personal communication).

Another important presence is Neomys cfr. milleri. Like Arvicola italicus also water shrews Neomys spp. suffer for the modifications to their habitats (Amori et al., 2008). At present, the only certain record of Miller's water shrew N. milleri in Campania refers to a skull recovered from pellets of barn owl collected on 8 April 1996 at Guardia Lombardi (province of Avellino) and kept at the Zoological Museum of the University of Naples Federico II with catalogue number Z6256 (Nappi \& Maio, 2002; Carpino \& Capasso, 2012). In Campania, also this species is included in the "Vulnerable" IUCN category (Carpino \& Capasso, 2012). The other species of the same genus, the Eurasian water shrew Neomys fodiens, is included in the category "Data Deficient" (Carpino \& Capasso, 2012). The records of Dinardo (1991a) for the Vesuvius area and dating at the beginning of the 1980s, were not confirmed later (Maio et al., 2000; Capasso et al., 2010), while a record for the National Park of Cilento and Vallo di Diano (Picariello et al., 1999) is unreliable due to the lack of further evidence, not to mention the difficulty to correctly separate the two Neomys species (Carpino \& Capasso, 2012).

The effective size of the Soricidae sample in particular could have been underestimated because their remains, usually fragile, could be preserved only partially in similar environmental conditions.

Considering the limitations involved in analysing this type of remains, such as the difficulty of correctly identifying them at species level, and the different ways in which different remains have been preserved over time (including the likely destruction of a significant part of them) it was possible to make some ecological considerations about the small mammal community and the environment they inhabit by using ecological indices (Tab. 2). In particular, the Margalef index and the Trophic Level Index returned high values when compared to those calculated for other sites from Campania. Basing on these results, one can hypothesize the ancient presence of a rich ecosystem in good ecological conditions. The agronomicenvironmental index is suggestive of the presence of open environments interspersed with wooded and/or bushy areas. Finally, the index of thermoxerophilia allows us to assume the existence of a Mediterranean climate also in the past, in view of the clear prevalence of Crocidurinae.

In conclusion, the study confirms the importance of studying archaeozoological remains, including those referred to the most recent periods of the Pleistocene, in order to assess ancient faunal associations suggestive of past environmental conditions. For this reason and for its implications in delineating the environmental background underlying the cultures of the past, the collection of small mammal remains should be encouraged during the digging operations and restoration interventions in archaeological sites. 
Tab. 2 - Values of some qualitative-quantitative indices on the small mammals' population of the Temple of Neptune and by comparison of other present-day sites from Campania. / Valori di alcuni indici qualiquantitativi del popolamento di piccoli mammiferi del Tempio di Nettuno e per confronto con altri siti attuali della Campania. D) Margalef index. / Indice di Margalef. TLI) Trophic level index. / Indice di livello trofico. A) Agronomic-environmental index. / Indice agronomico-ambientale. TX) Thermoxerophilia index. / Indice di termoxerofilia. ${ }^{1}$ Nappi (1998/99); ${ }^{2}$ Capasso et al. (2010); ${ }^{3}$ Viglietti (1997/98); ${ }^{4}$ Contoli (pers. com.); ${ }^{5}$ Russo \& Maglio (1996).

\begin{tabular}{|l|c|c|c|c|}
\hline & D & TLI & A & TX \\
\hline S. Giorgio La Molara $^{1}$ & 3.37 & 0.07 & 1.98 & 0.53 \\
\hline Gesualdo $^{1}$ & 2.56 & 0.07 & 0.72 & 0.25 \\
\hline Roccarainola $^{1}$ & 3.80 & 0.09 & 0.71 & 0.45 \\
\hline Avellino $^{1}$ & 1.84 & 0.03 & 1.37 & 0.93 \\
\hline Ottaviano $^{2}$ & 3.64 & 0.21 & 0.25 & 1 \\
\hline Portici $^{3}$ & 2.37 & 0.06 & 0.49 & 1 \\
\hline Persano $^{4}$ & 2.45 & 0.14 & 4,06 & 1 \\
\hline Castelcivita $^{5}$ & 2.82 & 0.14 & 0.31 & 1 \\
\hline Temple of Neptune & 2.94 & 0.21 & 0.89 & 0.97 \\
\hline S. Marco di Castellabate & & 1 \\
\hline Ogliastro Marina $^{1}$ & 2.42 & 0.05 & 0 & 1 \\
\hline
\end{tabular}

\section{Acknowledgements}

The restoration project, which led to the present research, was carried out by the Soprintendenza Archeologica di Salerno, the Direzione del Museo di Paestum and the Istituto Superiore per la Conservazione e il Restauro di Roma. Funding was made possible by the FIO Paestum Project and the Legge del Lotto del mercoledi Project.

Many thanks to Paolo Agnelli, Antonella Altieri, Marina Cipriani, Longino Contoli, Roberta Gaggi, Daniele Rossetti, Gabriel Zuchtriegel for their kind cooperation.

\section{REFERENCES}

Aloise G. \& Contoli L., 1984 - Su alcune valutazioni ambientali attraverso la dieta dei rapaci. Acqua-Aria, 2: 135-143.

Amori G., Cristaldi M. \& Contoli L., 1986 - Sui Roditori (Gliridae, Arvicolidae, Muridae) dell'Italia peninsulare ed insulare in rapporto all'ambiente bioclimatico mediterraneo. Animalia, 11 (1/3): 217-269 (1984).

Amori G., Contoli L. \& Nappi A. (eds.), 2008 - Mammalia II. Erinaceomorpha, Soricomorpha, Lagomorpha, Rodentia. Collana "Fauna d'Italia". Edizioni Calderini del Il Sole 24 ORE Business Media Srl, Milano, XLIV.

Barbera C., Conte A. \& Virgili A., 1987 - Prime osservazioni sulle mammalofaune della Grotta dell'Ausino (SA). Club Alpino Italiano, Sezione di Napoli, Notiziario Sezionale, 3: 31-35.

Bon M., Trabucco R. \& Delfino M., 2001 - La fauna del pozzo romano di Lova (Laguna di Venezia, I sec. a.C.
- I sec. d.C.). Bollettino del Museo Civico di Storia naturale di Venezia, 51: 159-185 (2000).

Cagnin M., 2008 - Arvicola amphibius (Linnaeus, 1758). Distribuzione geografica. In: Mammalia II. Erinaceomorpha, Soricomorpha, Lagomorpha, Rodentia. Collana "Fauna d'Italia". Amori G., Contoli L. \& Nappi A. (eds.). Edizioni Calderini del Il Sole 24 ORE Business Media Srl, Milano, XLIV: 450-452.

Capasso S. \& Carpino F., 2008 - Primi dati sulle comunità di micromammiferi del Parco Regionale del Partenio e valutazione della qualità ambientale. Hystrix, the Italian Journal of Mammalogy (n.s.), supp.: 74.

Capasso S., Carpino F., Conti P. \& Sammicheli F., 2010 Utilizzo dei micromammiferi come bioindicatori per la valutazione ambientale di un'area campione del Parco nazionale del Vesuvio. In: Convegno Italiano sui Piccoli Mammiferi. Bertolino S., Capizzi D., Mortelliti A. \& Amori G. (eds.). Libro dei riassunti: 29.

Capolongo D. \& Caputo V., 1990 - Mammals of the Partenio Mountains (Campanian apennines, Southern Italy). Vie Milieu, 40 (2/3): 156-159.

Caputo V., 1989 - I vertebrati del Massiccio del Partenio (Appennino campano). Atti del Circolo Culturale B. G. Duns Scoto di Roccarainola, 14/15: 214-283.

Carpino F. \& Capasso S., 2012 - Erinaceomorfi, Soricomorfi e Roditori. In: Lista rossa dei vertebrati terrestri e dulciacquicoli della Campania. Fraissinet M. \& Russo D. (eds). Regione Campania, Assessorato all'Ecologia ed alla Tutela dell'Ambiente, Settore Ecologia, Laboratorio di Ecologia Applicata, Dipartimento di Arboricoltura, Botanica e Patologia Vegetale, Facoltà di Agraria, Università degli Studi di Napoli Federico II: 101-119. 
Castelli A. \& Contoli L., 1985 - Valutazione di Parchi naturali in progetto e relativi studi. In: Ecologia. Moroni A., Anelli A. \& Ravera O. (a cura di). Atti del Secondo Congresso Nazionale della Società Italiana di Ecologia, 5 (2): 1049-1052.

Chaline J., 1970 - La signification des Rongeurs dans les dépôts quaternaires. Bulletin de l'Association Française pour l'Étude du Quaternaire, 4: 229-241.

Chaline J., 1973 - Biogéographie et fluctuations climatiques au Quaternaire d'après les faunes de rongeurs. Acta Zoologica Cracoviensia, 18 (7): 141-165.

Chaline J., 1977 - Essai de biostratigraphie et de correlations climatiques du Pléistocène inférieur et continental Holartique d'après l'évolution et la dynamique des migrations de rongeurs. Recherches françaises sur le Quaternaire INQUA 1977. Supplément au Bulletin AFEQ, 50: 349-361.

Chaline J., 1981 - Tentative West-European Rodents biozonation of the last glaciation. Quaternary Studies in Poland, 3: 5-13.

Contoli L., 1976 - Predazione di Tyto alba su micromammiferi e valutazioni sullo stato dell'ambiente. Atti VI Simposio Nazionale sulla Conservazione della Natura, Bari: 229-243.

Contoli L., 1980 - Borre di Strigiformi e ricerca teriologica in Italia. Natura e montagna, 27 (3): 73-94.

Contoli L., 1981 - Approcci ecologici per la tutela della fauna mediante aree naturali protette. In: Ecologia. Moroni A., Ravera O. \& Anelli A. (a cura di). Atti del Primo Congresso Nazionale della Società Italiana di Ecologia, 1: 51-55.

Contoli L., 1985 - L'individuazione dei sistemi territoriali di speciale interesse naturalistico: criteri e metodi. In: Ecologia. Moroni A., Anelli A. \& Ravera O. (a cura di). Atti del Secondo Congresso Nazionale della Società Italiana di Ecologia, 5 (2): 10431047.

Contoli L., 1988 - Validità ambientale e diversità trofica: indici vegetazionali e zoocenotici a confronto. Braun - Blanquetia, 2: 249-255.

Cuenca-Bescós G., Straus L. G., González Morales M. R. \& García Pimienta J. C., 2009 - The reconstruction of past environments through small mammals: from the Mousterian to the Bronze Age in El Mirón Cave (Cantabria, Spain). Journal of Archaeological Science, 36: 947-955.

De Palma G. (ed.), 2019 - I templi di Paestum tra restauro e manutenzione. Gangemi Editore, Roma.

Dinardo L., 1991a - Gli Insettivori dell'area del SommaVesuvio. II parte. Summana, 23: 26-29.

Dinardo L., 1991b - I Roditori dell'area Somma-Vesuvio. Terza e ultima parte. Summana, 21: 19-21.

Jancarik A. \& Horacek I., 1988 - Fauna subfossile di piccoli mammiferi della Grotta dell'Ausino (M. Alburni) in Italia meridionale. L'Appennino meridionale. Annuario del Club Alpino Italiano, Sezione di Napoli: 185-186.

Kotsakis T. \& Ruschioni E., 1984 - I microvertebrati di un insediamento dell'Età del Ferro presso Tortoreto (Teramo, Italia centrale). Rendiconti dell'Accademia Nazionale dei Lincei, serie 8, 76: 295-304.
Kowalski K., 1966 - The stratigraphic importance of rodents in the studies on the European Quaternary. Folia Quaternaria, 22: 1-16.

Kowalski K., 1992 - Remarks on the zoogeography of Quaternary Rodents in Europe. Courier Forschungsinstitut Senckenberg, 153: 197-203.

López-García J. M., Blain H.-A., Morales J. I., Lorenzo C., Bañuls-Cardona S. \& Cuenca-Bescós G., 2013aSmall-mammal diversity in Spain during the late Pleistocene to early Holocene: climate, landscape, and human impact. Geology, 41 (2): 267-270.

López-García J. M., Blain H. A., Pagano E., Ollé A., Vergès J. M. \& Forgia V., 2013b - The small mammals (insectivores, bats and rodents) from the Holocene archaeological site of Vallone Inferno (Scillato, Lower Imera valley, Northwestern Sicily). Rivista Italiana di Paleontologia e Stratigrafia, 119 (2): 229-244.

Loy A., Aloise G., Ancillotto L., Angelici F. M., Bertolino S., Capizzi D., Castiglia R., Colangelo P., Contoli L., Cozzi B., Fontaneto D., Lapini L., Maio N., Monaco A., Mori E., Nappi A., Podestà M., Russo D., Sarà M., Scandura M. \& Amori G., 2019 - Mammals of Italy: an annotated checklist. Hystrix, the Italian Journal of Mammalogy, 30 (2): 87-106. <https://doi.org/10.4404/ hystrix-00196-2019>.

Maio N., Aprea G., D’Amora G. \& Picariello O., 2000 Teriofauna del Parco Nazionale del Vesuvio. In: Elementi di biodiversità nel Parco Nazionale del Vesuvio. Picariello O., di Fusco N. \& Fraissinet M. (eds.). Parco Nazionale del Vesuvio, Napoli: 215245.

Marzilli A. \& Contoli L., 1991 - Metodologie informatiche applicate alla relazione "diversità trofica-ambiente". In: L'ecologia dell'eterogeneita. Farina A. (a cura di). Società Italiana di Ecologia, Atti del Seminario di studio (Aulla, 12 aprile 1991), 12: 971-976.

Nappi A., 1998/99 - I micromammiferi della Campania. Tesi di Laurea. Università degli Studi di Napoli Federico II, Facoltà di Scienze Matematiche, Fisiche e Naturali, Corso di Laurea in Scienze Naturali, Dipartimento di Zoologia.

Nappi A., 2000 - Osservazioni preliminari sulle popolazioni preistoriche e attuali dei micromammiferi dei Monti Alburni (Salerno) in rapporto al clima. Sentiero degli dei, Notiziario della Sezione di Napoli del Club Alpino Italiano, 3 (2): 25-30.

Nappi A., 2001 - I micromammiferi d'Italia. Edizioni Simone, Napoli.

Nappi A., 2004a - L'Arvicola terrestre Arvicola terrestris (Linnaeus, 1758): una specie da proteggere? La voce del Gheppio, supplemento al Notiziario A.R.C.A., 1 (1): 2-9.

Nappi A., 2004b - L'importanza dello studio dei micromammiferi nelle aree protette. In: Meeting della divulgazione scientifica. Università degli Studi di Napoli Federico II, Facoltà di Scienze Matematiche, Fisiche e Naturali, Biologi domani EUREKA, Universitari per le Scienze: 75-131.

Nappi A., 2010 - Considerazioni sui resti di micromammiferi rinvenuti durante il restauro del Tempio di Nettuno a Paestum (provincia di Salerno). In: Convegno 
Italiano sui Piccoli Mammiferi. Bertolino S., Capizzi D., Mortelliti A. \& Amori G. (eds.). Libro dei riassunti: 44.

Nappi A., 2011 - L'analisi delle borre degli uccelli: metodiche, applicazioni e informazioni. Un lavoro monografico. Picus, 37 (72): 106-120.

Nappi A. \& Maio N., 2002 - Gli Insettivori del Museo Zoologico dell'Università di Napoli Federico II (Mammalia, Insectivora). Catalogo della collezione con note storiche. Atti del Museo Civico di Storia Naturale di Trieste, 49: 187-201.

Niethammer J., 1969 - Zur Frage der Introgression bei den Waldmäusen Apodemus sylvaticus und A. flavicollis. Zeitschrift für zoologisches Systematik und Evolutionforschung, 7: 77-127.

Pardiñas U. F. J., Moreira G. J., Garcia-Esponda C. M. \& De Santis L. J. M., 2000 - Deterioro ambiental y micromamíferos durante el Holoceno en el nordeste de la estepa patagónica (Argentina). Revista Chilena de Historia Natural, 73: 9-21.

Pasa A., 1959 - Ricerche sulla fauna appenninica. XXXIX. Alcuni caratteri delle mammalofaune dei Monti Picentini (Appennino Campano). Memorie del Museo Civico di Storia Naturale di Verona, 7: 235-245.

Picariello O., Fraissinet M. \& Maio N., 1999 - Gli animali selvatici del Parco Nazionale del Vesuvio e del Cilento-Vallo di Diano. In: La "rete" MAB nel Mediterraneo. Parchi Nazionali del Cilento Vallo di Diano e del Vesuvio. Il ruolo dell'UNESCO. Lucarelli F.(ed.). Studio Idea, Napoli: 347-383.

Raicaldo P., 2020 - Sorpresa sul Sarno, spunta un nuovo mammifero per la zona: l'arvicola. $L a R e-$ pubblica, Napoli.it <https://napoli.repubblica.it/ cronaca/2020/06/23/foto/sorpresa sul sarno spunta un_nuovo_mammifero 1 arvicola-259965880/1/\#1>-

Russo D., $1 \overline{997}$ - Primi dati sulla comunità ornitica dell'area protetta "Torre di Mare" (Capaccio - Salerno). Gli Uccelli d'Italia, 22 (1): 18-25.

Russo D. \& Maglio G., 1996 - Spettro trofico del barbagianni Tyto alba (Scopoli) in un'area rurale della Campania. Acta Medica Veterinaria, 42: 149-158.

Scaravelli D. \& Priori P., 2009 - Parco Regionale Roccamonfina Foce Garigliano. Guida alla conoscenza degli habitat. Fauna. Filograf, Forlì.

Viglietti S., 1997/98 - Analisi stagionale dell'alimentazione del barbagianni nel Parco Gussone di Portici. Tesi di Laurea. Università degli Studi di Napoli Federico II, Facoltà di Scienze Matematiche, Fisiche e Naturali, Corso di Laurea in Scienze Naturali, Dipartimento di Zoologia.

Vigne J.-D., 1996 - Small mammal fossil assemblages as indicators of environmental change in Northern Corsica during the last 2500 years. Journal of Archaeological Science, 23: 199-215.

Zangirolami A., 1988/1989 - Analisi del popolamento di micromammiferi dell'Alto Luinese mediante lo studio dell'alimentazione dell'Allocco (Strix aluco). Tesi di Laurea in Scienze Biologiche, Università di Milano. 